\title{
THE SIZE OF Araucaria angustifolia (Bertol.) Kuntze ENTERING INTO REPRODUCTIVE STAGES AS A BASIS FOR SEED MANAGEMENT PROJECTS ${ }^{1}$
}

Giovani Festa Paludo ${ }^{2 *}$, Roberta Inácia Duarte ${ }^{3}$, Alison Paulo Bernardi ${ }^{4}$, Adelar Mantovani $^{5}$ and Maurício Sedrez dos Reis ${ }^{6}$

\footnotetext{
${ }^{1}$ Received on 10.01.2013 accepted for publication on 24.05.2016.

${ }^{2}$ Universidade Federal de Santa Catarina, Programa de Pós-Graduação em Ecologia, Florianópolis, Santa Catarina, Brasil. E-mail:<gfpaludo@gmail.com>.

${ }^{3}$ Universidade Federal de Santa Catarina, Graduada em Agronomia, Florianópolis, Santa Catarina, Brasil. Email: $<$ robertaduarte142@gmail.com>.

${ }^{4}$ Universidade Federal de Santa Catarina, Programa de Pós-Graduação em Recursos Genéticos Vegetais, Florianópolis, Santa Catarina - Brasil. Email: <bernardialison@gmail.com>.

${ }^{5}$ Universidade do Estado de Santa Catarina, Departamento de Engenharia Florestal, Centro de Ciências Agroveterinárias, Lages, Santa Catarina - Brasil. Email: <adelar.mantovani@udesc.br>.

${ }^{6}$ Universidade Federal de Santa Catarina, Departamento de Fitotecnia, Centro de Ciências Agrárias, Florianópolis, Santa Catarina - Brasil. Email: <m.s.reis@ufsc.br>.

*Corresponding author.
}

\begin{abstract}
In order to plant parana-pines (Araucaria angustifolia (Bertol.) Kuntze) for seed production, as for any other forest management activity, planning is needed, especially because of the significant amount of waiting time between planting and seed collection. Consequently, there is a lack of basic ecological information. Several studies based on the demography of the $A$. angustifolia fail to divulge which sized individuals are reproductive. This paper investigated the relationship between the reproductive stage and the diameter at breast height (d.b.h.), and attempted to establish a size where a great portion of the individuals had already begun their reproductive process, a considerable step for subsidizing technical projects for seed production. Five study sites located in four municipalities in the state of Santa Catarina composed a total sample area of 31.6 ha. All $A$. angustifolia individuals with a height greater than $1.5 \mathrm{~m}$ within the sampled area were measured and classified according to their reproductive phase. A total of 1,843 individuals were obtained: 383 were male, and 299 were female. There was a significant relationship between the d.b.h. and the sexual maturity of the individuals. The reproductive process begins inside the DAP class of $15-20 \mathrm{~cm}$, but only $8 \%$ of the individuals reproducing. In order to find a greater number of individuals in reproduction, a minimum d.b.h. of $35.2 \mathrm{~cm}$ is required. In conclusion, projects that produce araucaria nuts should consider this d.b.h. size to commence production. This species has great potential for agroforestry systems within the Araucaria Forests. This basic ecological information is also important for the construction of projects that use this species, and consequently may contribute to the conservation of this forest. This can be used as a study case for other forest species and ecosystems to explore the potential production of non-timber forest products of native resources.
\end{abstract}

Keywords: Araucaria nut; Cones; Non-timber forest products.

\section{TAMANHO EM QUE Araucaria angustifolia (Bertol.) Kuntze INICIA A PRODUÇÃO DE SEMENTES COMO UM DOS SUBSÍDIOS PARA PROJETOS DE MANEJO DO PINHÃO}

RESUMO - Plantar pinheiros-do-paraná para a produção de sementes - o pinhão - como qualquer outra atividade de manejo florestal, exige um planejamento, já que são necessários vários anos entre o plantio e o início da produção de sementes. Neste sentido, faltam informações ecológicas básicas. Muitos estudos de demografia de Araucaria angustifolia (Bertol.) Kuntze pecam em não trazer uma simples informação ecológica: em quais tamanhos os indivíduos iniciam o processo reprodutivo? Foi investigada a relação entre 


\begin{abstract}
o tamanho em diâmetro à altura do peito (DAP e medido a $1,3 \mathrm{~m}$ do solo) e o estágio reprodutivo e foi procurado estabelecer um tamanho em que grande parte dos individuos já entraram no processo reprodutivo como mais um subsídio para a construção de projetos de viabilidade técnica para a produção de sementes. Foram amostrados cinco sítios em remanescentes da Floresta com Araucárias distribuídos ao longo do estado de Santa Catarina e no total compuseram uma área amostral de 31,6 ha. Nesta área amostral foram amostrados todos os indivíduos de Araucaria angustifolia com altura $>1.5 \mathrm{~m}$ e verificado o estágio reprodutivo. Ao final foram obtidos 1843 indivíduos, sendo que 383 pertencentes ao sexo masculino e 299 ao feminino. Como resultado, existiu relação significativa entre o DAP e o estágio reprodutivo. O processo reprodutivo inicia dentro da classe de DAP de 15-20 cm, mas com apenas $8 \%$ dos indivíduos em fase reprodutiva. Para encontrar grande parte de indivíduos em estágio reprodutivo (90\%), o DAP deve ser no mínimo de 35, $2 \mathrm{~cm}$. Como conclusão, é sugerido que projetos para a produção de sementes considerem esse tamanho como o início do processo reprodutivo. Araucaria angustifolia é uma espécie com grande potencial de utilização em sistemas agroflorestais na floresta ombrófila mista, e estas informações ecológicas básicas são importantes para possibilitar a construção de projetos voltados ao uso desta espécie. Este trabalho é um exemplo de uma alternativa para modelar a produção um produto florestal não-madeireiro para outras espécies e ecossistemas.
\end{abstract}

Palavras-chave: Floresta com araucárias; Cones; Produto florestal não-madeireiro.

\section{INTRODUCTION}

Ecology is the basis of silviculture (HAWLEY; SMITH, 1972) and its understanding is what drives proper forest management of both wood and non-wood products (McPHERSON; DeSTEFANO, 2003). Controversially, management of ecosystems often ignores ecological theory, and many ecological investigations are carried out without appropriate consideration for management activities (McPHERSON; DeSTEFANO, 2003). Many studies could contribute to management by providing ecological information. However, the way the information is tabulated prevents its use.

Araucaria angustifolia (Bertol.) Kuntze is used as an example to highlight the lack of knowlegde of ecosystem management. Its family, Araucariaceae, is almost exclusively austral and consists of two neotropical species: A. angustifolia and A. araucana (Molina) C. Koch. These two species produce seeds commonly known as araucaria nuts ("pinhões" in Portuguese), an important non-timber forest product (NTFP), of high nutritional, cultural and socioeconomic value (VIEIRADA-SILVA; REIS, 2009; REIS et al., 2010; VIEIRA-DASILVA et al., 2011; REIS; LADIO, 2012), historically known for its wide use by humans (BITENCOURT; KRAUSPENHAR, 2006; REIS; LADIO, 2012).

Despite the great amount of studies on various ecological and biological aspects of $A$. angustifolia, including symbiotic associations (ZANDAVALLI et al., 2004), animal interactions (IOB; VIEIRA, 2008), demographics (SOLÓRZANO-FILHO, 2001;
PUCHALSKY et al., 2006; SOUZA, 2007; SOUZA et al., 2008), dendrochronology (OLIVEIRA et al., 2009), and physiological development (DUARTE; DILLENBURG, 2000), and in many other fields, many basic ecological questions regarding their population remain unanswered. For example, the creation of a production area for araucaria nuts demands basic ecological understanding on growth, sexual maturity and seed production of such individuals to establish adequate planting techniques. In other words, many questions must be answered: What is the required time for an individual to grow to a desired size? Is there a relationship between diameter and the early reproductive phase? How many seeds does each individual produce? The first and third questions have been addressed in the works addressing species increment in forests (MATTOS et al., 2007), factors influencing the d.b.h. (diameter at breast height) increment (FIGUEIREDO-FILHO et al., 2003; HOPPE; CALDEIRA, 2003), per capita seed production (MANTOVANI et al., 2004; VIEIRA-DA-SILVA; REIS, 2009; FIGUEIREDO-FILHO et al., 2011) and variation in seed production (MANTOVANI et al., 2004; SOUZA et al., 2010), among others. As for the second question, demographic studies have not tabulated the data yet (examples: PUCHALSKI et al., 2006; SOUZA, 2007; PALUDO et al., 2009). A similar situation is found for $A$. araucana, with studies on the issues mentioned above (VEBLEN, 1982; IBANEZ, 1984; DRAKE et al., 2005; SANGUINETTI; KITZBERGER, 2008). However, there is a lack of studies that attempt to assess the relationship between diameter and the reproductive 
phase. Although reproductive behaviour is age-specific, much of the reproductive behaviour of perennial plants appears to be more specific to size than age (HARPER, 1977).

The relationship between size (diameter) and the reproductive phase could be an important element for planning the use of these resources (seeds). Forest management practices are often long-term, thus requiring specific projects in order to guarantee their economic, technical, financial, and environmental feasibility (REZENDE; OLIVEIRA, 2011). Therefore, in order to estimate araucaria nut production, knowing when individuals enter the reproductive phase and how much they can produce is crucial information. Without such data, it is not possible to calculate the financial return of the product. For parana-pine, for example, the araucaria nut market is an alternative to the traditional wood use market, which greatly benefits the ecosystem and the conservation of this species' role in the market. It is notorious the need for incentives for activities aiming at the sustainable use of Araucaria forest resources (VIBRANS et al., 2011). Moreover, the lack of technical knowledge on forest resources is one of the reasons for the common replacement of native resources by resources from exotic species (SIMINSKI; FANTINI, 2010).

Therefore, this work aims to present estimates for the size class in which Araucaria angustifolia enters the reproductive stage at regional (in the state of Santa Catarina) and local (within the study site) levels. The result in turn could help management and project planning for A. angustifolia seed extraction. The following questions were addressed: (i) is there a relationship between size (d.b.h.) and reproductive phase? (ii) Which size class is the first that contains a larger number of individuals in reproductive phase? (iii) At which size class (d.b.h.) does the reproductive phase begin? All three questions were addressed on a regional scale (joining populations) and local scale (in each population).

\section{MATERIALAND METHODS}

\subsection{Species of Interest}

Araucaria angustifolia is a coniferous, dioecious, anemophyle species, naturally occurring in the Southern Brazil. The reproduction of this species occurs once a year, and it takes up to two years from the time of the first appearance of a cone to the time in which the seeds fall (MANTOVANI et al., 2004). In the last century, the wood from $A$. angustifolia was a great contributor for the export of Brazilian products (REITZ et al., 1978), and the extensive devastation of its forests has reduced $A$. angustifolia populations (RIBEIRO et al., 2009) and led it to a critical conservation state (IUCN, 2012). Additionally, due to the lack of ecological information for this species, its seeds are collected without guaranteeing the maintenance of its populations.

\subsection{Study Site and Data Collection}

This study was performed in five sites, distributed among 4 municipalities in the state of Santa Catarina, Brazil, Southern America. In the first, located in the Três Barras National Forest (known as Flona de Três Barras), 12 sampling units measuring 40 x 40 m (1.92 ha) were installed and systematically distributed in the medium and advanced staged areas of the forest. In the Reserva Genética Florestal de Caçador (known as the Reserva de Caçador), 1 sample unit of $170 \mathrm{x}$ $300 \mathrm{~m}$ (5.1 ha) was installed in areas characterized as a primary forest. In the Coxilha Rica Region, in the municipality of Lages, one sample unit of $300 \mathrm{x}$ $300 \mathrm{~m}$ (9 ha) was installed in an area used for grazing (bovine pastures), which suffered selective cuts 35 years ago. Coxilha Rica differs from the other area since it was the only area sampled in a savanna (grassland with forest patches) landscape. Similarly, in the Parque Natural Municipal de Lages (known as Parnamul), all individuals were sampled within a polygon of 8.0 ha. The historical exploitation of Parnamul is unknown, although the characteristics of this forest suggest a good conservation status. Lastly, in Urubici municipality, in the RPPN Leão da Montanha, an area was sampled within a polygon of $7.6 \mathrm{ha}$. In this site, parana-pine extraction was carried out until 1990. Then, the area was utilized for pasture until 2006, when this site was converted to a RPPN (Private Reserve of Natural Heritage or "Reserva Particular do Patrimônio Natural"). At every study site, all individuals with heights $>1.5 \mathrm{~m}$ were identified and measured: diameter at breast height (d.b.h. where breast height was considered as $1.30 \mathrm{~m}$ above ground) and total height. For all individuals within the study sites, the reproductive parts were observed using binoculars, according to Mantovani et al. (2004). Individuals lacking reproductive structures at the time of evaluation (within a year) were classified as non-reproductive.

Revista Árvore, Viçosa-MG, v.40, n.4, p.695-705, 2016

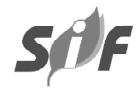




\subsection{Data Analysis}

To determine the relationship between d.b.h. and the reproductive phase, a binary logistic regression (CRAWLEY, 2007) was performed, a special case of Generalized Linear Models (LEGENDRE; LEGENDRE, 1998). Using the equation between reproductive phase (zero for non-reproductive and one for reproductive), the d.b.h. at which a large part of individuals were in their reproductive phase was calculated. Then, the logistic regression provided an equation to estimate the probability of an individual occurring in a reproductive phase in a function of the d.b.h.:

Probability (reproductive phase) $=1 /\left(1+e^{-(\beta 0}\right.$ $+\beta 1 *$ d.b.h.),

where d.b.h. is diameter at breast height in centimeters, and the result varies between zero and one; zero is significantly non-reproductive, and one, significantly reproductive.

Populations were compared using the $\beta_{1}$ regression coefficient odds ratio (OR), using a $95 \%$ confidence interval $\left(\mathrm{OR}=\mathrm{e}^{\beta 1 \pm 1.96 * \text { stderror }(\beta 1)}\right)$. Graphical representations were produced to better visualize the proportions of reproductive and non-reproductive individuals in 5$\mathrm{cm}$ size classes. The results of potentially reproductive d.b.h. classes were obtained through these graphs (where less than $85 \%$ or $90 \%$ of the individuals of such class were in the reproductive phase) and through logistic regressions. The beginning of the reproductive phase was inferred from the smallest d.b.h. size of the population in a reproductive phase. Analyses were conducted using algorithms constructed in R ( R Development Core Team, 2012).

\section{RESULTS}

For all sites, 1843 individuals $>1.5 \mathrm{~m}$ were counted (31.6 ha sampled). Of these, 383 were male and 299 female, and 1161 individuals were non-reproductive. At the regional scale (state of Santa Catarina), it was observed that the reproductive process started at the size interval between 15 and $20 \mathrm{~cm}$ of d.b.h. (Figure 1), in which $2 \%$ of the individuals were female; $6 \%$, male; and $92 \%$, non-reproductive. Also, as observed in Figure 1 , the first d.b.h. class presenting a high proportion of reproductive individuals was between 30 and 35 $\mathrm{cm} ; 30 \%$ were female, $58 \%$ male, and $12 \%$ nonreproductive.
For the total population, the logistic regression showed a significant relationship between diameter at breast height and reproductive phase $(z=18.69$; $\mathrm{P}<0.001$; Residual error $=680$ and $\mathrm{DF}=1841$; Figure 2 ). The probability of an $A$. angustifolia individual occurring in a reproductive phase in function of the d.b.h. was determined by:

Probability (reproductive phase) $=1 /\left(1+e^{-(-6.4803}\right.$ $+0.24629 *$ d.b.h.) $)$,

where d.b.h. is the diameter at breast height in centimeters, and the result ranges between zero and one; zero means significantly non-reproductive, and one, significantly reproductive.

According to the equation, the d.b.h. at which $90 \%(\mathrm{P}=0.9)$ of the individuals would be in a reproductive phase was $35.2 \mathrm{~cm}$; and the value at which $50 \%$ of the individuals would be in the same phase was 26.3 cm (Figure 2).

When each population was analyzed separately, all regressions were found significant $(\mathrm{P}<0.001)$. For the Reserva de Caçador: Prob $=1 /\left(1+e^{-(-7.61299+0.26070}\right.$ *d.b.h.) $)$; For Parnamul: Prob $=1 /\left(1+e^{-(-4.02646+0.16243}\right.$ *d.b.h.) $)$; For Flona de Três Barras: Prob $=1 /\left(1+e^{-(-8.51437}\right.$ $+0.38377 *$ *.b.h. $)$; For Coxilha Rica: Prob $=1 /\left(1+e^{-(-7.48431+}\right.$ $0.30671^{*}$ d.b.h.) $)$; For the RPPN Leão da Montanha: Prob $=1 /\left(1+e^{-(-6.77452+0.23409 * d . b . h .)}\right)$. The order of the populations at which the probability of having an individual in the reproductive phase is equal to 0.9 , or at which proportion has $90 \%$ of the individuals in reproductive phases is: Flona de Três Barras; Coxilha Rica; Reserva de Caçador, Parnamul and RPPN Leão da Montanha, with d.b.h. of 27.9, 31.6, 37.6, 38.3 and $38.3 \mathrm{~cm}$, respectively (Figure 3).

As shown in Figure 4, for Parnamul at the local scale (at each site), the d.b.h. class was $15-20 \mathrm{~cm}$ for individuals in the initial reproductive phase, where only $6 \%$ were male individuals (Figure 4 ). The class that showed the highest proportion of reproductive individuals (100\% respectively) had d.b.h. of 25-30 $\mathrm{cm}$. In the RPPN Leão da Montanha, the reproductive phase started between 15 and $20 \mathrm{~cm}$, and $19 \%$ of the individuals were reproductive. The first class presenting a high proportion of reproductive individuals had a d.b.h. of $35-40 \mathrm{~cm}$, which included $84 \%$ of the individuals.

In the Reserva de Caçador, the reproductive phase started between 15 and $20 \mathrm{~cm}$, and $4 \%$ of the individuals were reproductive. The class between 35 and $40 \mathrm{~cm}$ 

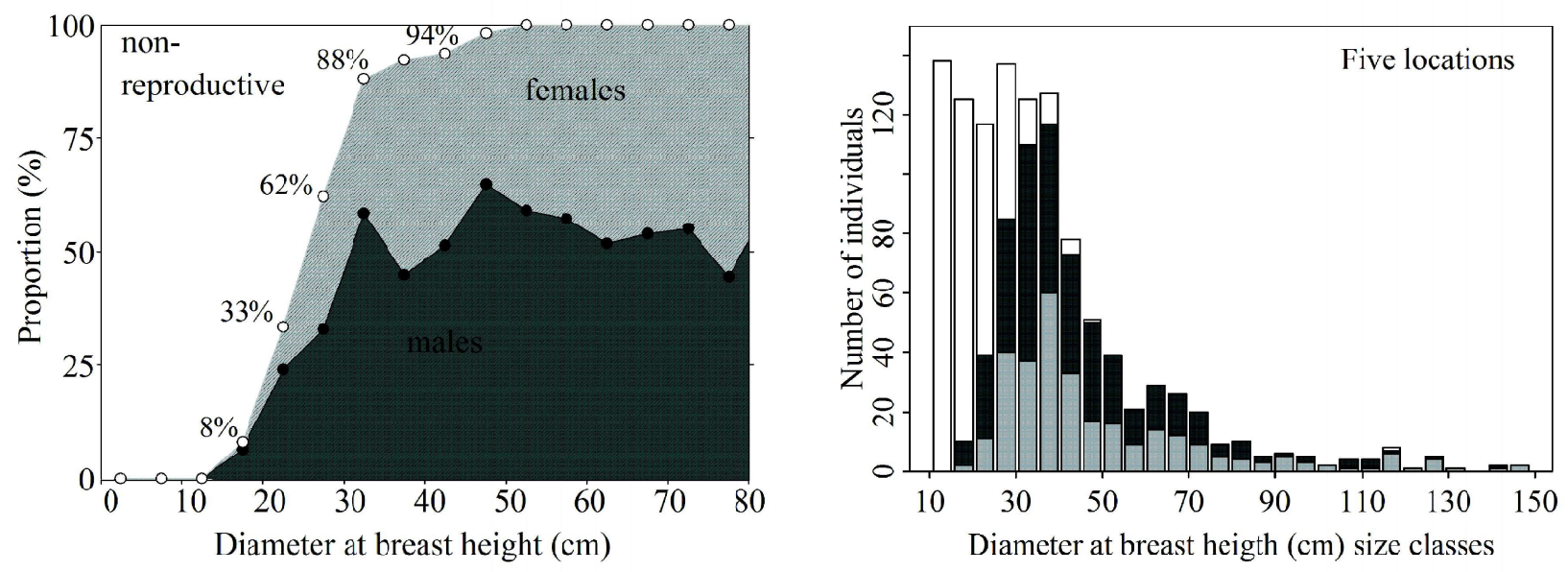

Figure 1 - Proportions (left) and distribution (right) of individuals of Araucaria angustifolia in diameter at breast height size classes. White represents non-reproductive individuals, gray represents females and dark gray represents male individuals sampled from five populations of $A$. angustifolia distributed throughout the state of Santa Catarina, Brazil.

Figura 1 - Proporção (direita) e distribuição (esquerda) dos mesmos números de indivíduos por classes de diâmetro altura do peito. Sendo que se trata dos indivíduos femininos (cinza claro), masculinos (cinza escuro) e não-reprodutivos (branco) de Araucaria angustifolia amostrados em 31,6 ha em cinco locais de ocorrência no estado de Santa Catarina, Brasil.

of d.b.h. was the first class presenting a high proportion of reproductive individuals, $88 \%$. The Coxilha Rica area showed maturation at d.b.h. between 15 and 20 $\mathrm{cm}$, and $17 \%$ of them were in reproductive phase. Here, the first size class with the highest proportion of reproductive individuals was between 30 and $35 \mathrm{~cm}$ of d.b.h., which included $93 \%$ of individuals reproducing. Lastly, in Flona de Três Barras, the first size class of reproductive individuals, was betweem 20 and $25 \mathrm{~cm}$ d.b.h., presenting $100 \%$ of reproducing individuals.

\section{DISCUSSION}

The results demonstrated that the initial reproductive phase for A. angustifolia occurs at a d.b.h. size of $15-20 \mathrm{~cm}$. Souza et al. (2008) studied populations in the state of Rio Grande do Sul, where the smallest reproductive individual recorded had a d.b.h. size of $10.5 \mathrm{~cm}$ (sex not defined). In A. angustifolia plantations in Paraná State, Figueiredo-Filho et al. (2011) reported difficulties in finding seed producers individuals in size classes of 20 to $30 \mathrm{~cm}$. Similar to our study, Mantovani (2003) also determined the initial reproductive phase at a d.b.h. size of 15 to $20 \mathrm{~cm}$ in São Paulo state. Despite the reproductive individuals found at a d.b.h. size of 15 to $20 \mathrm{~cm}$, the presented proportion of reproductive to non-reproductive individuals determined in our study (only $8 \%$ ) is the novelty for population ecology of parana-pines. Therefore, we suggest that future projects use other d.b.h. values. For example, we suggest the minimum d.b.h. value when most individuals attain the reproductive stage. As a significant relationship was detected between d.b.h. and reproductive phase (Figure 2 ), the logistic equation indicates that a minimum d.b.h. value of $35.2 \mathrm{~cm}$ must be considered in order to find a proportion equal or higher than $90 \%$ of the individuals reproducing. Result corroborated by visual analysis of Figure 1, in which the class $35-40$ has $92 \%$ of its individuals reproducing and the sexual ratio is close to 1 (proportion of male to female individuals). These results suggest that further projects planning for seed production of $A$. angustifolia should prioritize growing individuals up to a d.b.h. size of $35 \mathrm{~cm}$.

Among the studies that show the demographic structure of $A$. angustifolia, only Mantovani (2003) presented classes of reproductive individuals but did not address the remaining non-reproductive individuals. Considering the production of cones per d.b.h. size class, Figueiredo-Filho et al. (2011) showed that a d.b.h. between 30 and $40 \mathrm{~cm}$ was sufficient to produce cones. Solórzano-Filho (2001) addressed the percentage of sexual maturity according to the height classes, but not as a function of d.b.h., as conducted in our study, 


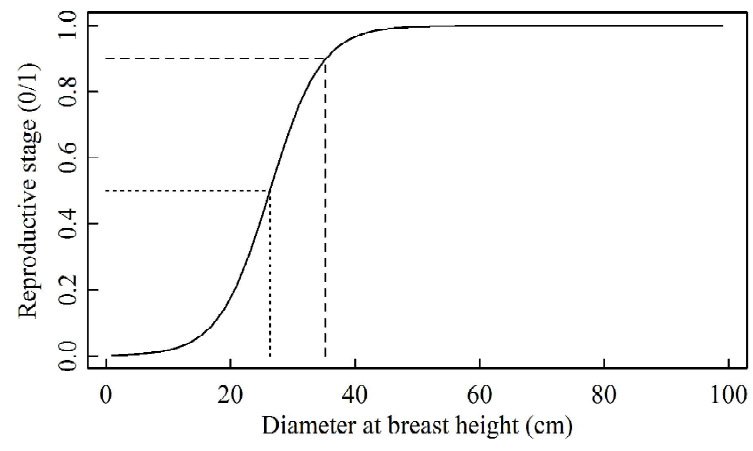

Figure 2 - Relationship between diameter at breast height and reproductive stage expressed by a logisticregression curve. The binary variable is represented by the y-axis, where the number 1 refers to the mature stage and the number 0 refers to the non-reproductive stage. The regression was based on five populations of Araucaria angustifolia represented by 1843 individuals with height greater than $1.5 \mathrm{~m}$ within an area of $31.6 \mathrm{ha}$. The dotted and dashed lines indicate the d.b.h. size in order to find a proportion equal to $50 \%$ and $90 \%$ of the individuals reproducing, respectively.

Figura 2 - Curva de regressão logística binária (linha contínua) indicando a probabilidade do indivíduo estar em estágio reprodutivo em função do Diâmetro à Altura do Peito (DAP). No eixo y o estágio reprodutivo é a variável binária onde zero representa não-reprodutivo e 1 significa que o indivíuo está em estágio reprodutivo. A regressão foi baseada em um conjunto de 1843 indivíduos obtidos em uma área amostral de 31,6 ha em 5 populações de Araucaria angustifolia de Santa Catarina, Brasil. Note que são destacados os valores de DAP para as probabilidades de encontrar o indivíduo no estágio reprodutivo com $p=0,5$ (linha pontilhada) e com o valor de $p=0,9$ (linha contínua).

which also tested for this relationship using statistical methods.

There were significantly differences between two sites: Parnamul differed from the population of Coxilha Rica, both found in the municipality of Lages. The remaining sites did not differ according to the $95 \%$ intervals derived from $\mathrm{z}$ distributions to ORs. In the present study, the individuals were not monitored throughout the years, which could explain the detected differences. This information was therefore inferred

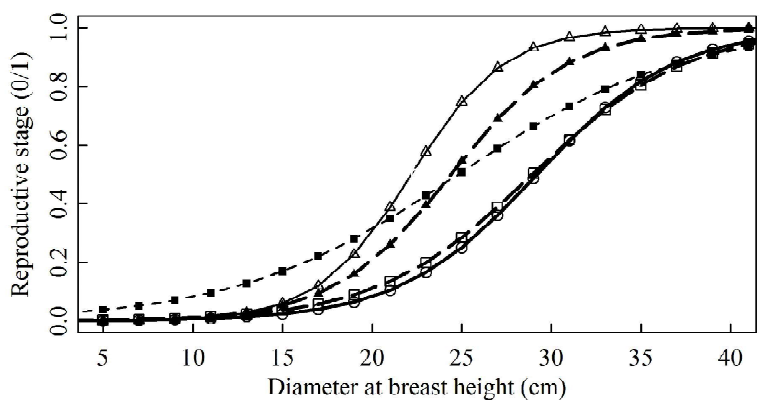

Figure 3 - Relationship between diameter at breast height and reproductive stage expressed by logisticregression curves. The binary variable is represented by the y-axis, where the number 1 refers to the mature stage and the number 0 , to the non-reproductive stage. Each line represents a population: Flona de Três Barras (empty triangles); Coxilha Rica (filled triangles); Parnamul (filled squares); RPPN Leão da Montanha (empty squares); and Reserva de Caçador (empty circles). These are study sites in Araucaria's Forest remnants located in four municipalities of Santa Catarina State, Southern Brazil.

Figura 3 - Curvas da regressão logística para relação entre o tamanho em diâmetro à altura do peito e estágio reprodutivo dos indivíduos de Araucaria angustifolia. No eixo y está o estágio reprodutivo (variável binária) onde zero representa nãoreprodutivo e um significa que o indivíduo está em estágio reprodutivo. Cada linha representa uma população: Três Barras (triângulos vazios), Coxilha (triângulos cheios), Parnamul (quadrados cheios), Urubici (quadrados vazios), Caçador (círculos vazios). São sítios de estudo instalados em remanescentes de floresta com Araucária situados em 4 municipios do estado de Santa Catarina, Sul do Brasil.

from the obtained d.b.h. of reproductive and nonreproductive individuals at one single time during the collection time. It is also possible that the few individuals in the transition stage, from immature to reproductive, could have provoked this difference at Parnamul.

Proper project planning requires not only the information from the beginning of the reproductive phase, but also requires knowledge of the time interval from the first sighting of cones until maturation. This time interval takes approximately 20 months (MANTOVANI et al., 2004; ANSELMINI; ZANETTE, 2008). 

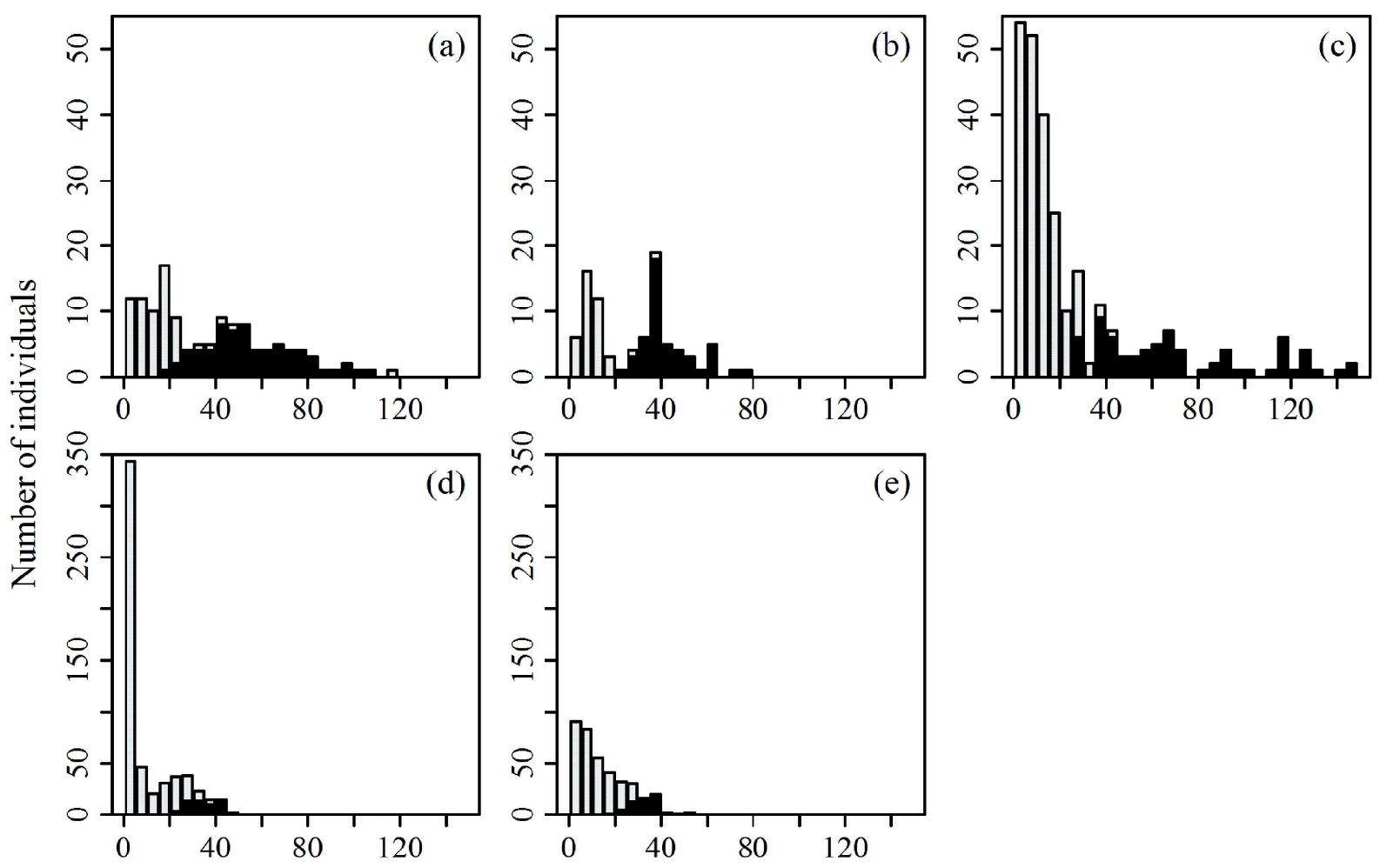

Diameter at breast heigth $(\mathrm{cm})$

Figure 4 - D.b.h. size class distribution of individuals of Araucaria angustifolia. Filled gray bars refer to non-reproductive individuals, filled dark-gray bars represent female individuals. Each graph corresponds to a population of $A$. angustifolia distributed throughout the state of Santa Catarina, Brazil. Where: (a) Parnamul; (b) Flona de Três Barras; (c) Reserva de Caçador; (d) RPPN Leão da Montanha and; (e) Coxilha Rica.

Figura 4-Distribuição de indivíduos não-reprodutivos (cinza-claro) e apenas indivíduos femininos (cinza-escuro) de Araucaria angustifolia em cada um dos cinco locais de Santa Catarina, Brazil. Onde: (a) Parnamul; (b) Flona de Três Barras; (c) Reserva de Caçador; (d) RPPN Leão da Montanha e; (e) Coxilha Rica.

The size of $A$. angustifolia at the reproductive phase is inferred from the regression between the reproductive phase (response variable: reproductive or not) and the diameter at breast height (d.b.h.). These results in conjunction with growth information will allow estimating the timing for seed collection. Moreover, with information of d.b.h., it is possible to estimate the potential of an area for cone production. Knowing the d.b.h., it will be possible to know how many individuals will be in reproduction.

All these insights are important for planning proper management uses of $A$. angustifolia, especially because future technologies and knowledge on Araucaria forests require immediate attention (ROSOT, 2007). Efforts towards the plantation of native species for economic purposes allow the conservation of other native species, as shown by Pietrek and Branch (2011) in an Argentinian plantation of $A$. angustifolia. Currently, one of the greatest challenges is transforming the potential uses of forest species into concrete realities, expecting to value them as providers of both goods and ecosystem services (ROSOT, 2007).

The maintenance of $A$. angustifolia in the landscape is of crucial importance since it provides many ecosystem services, providing branches for birds to roost, promoting interactions of facilitation of forest settlement (ZANINI; GANADE, 2005; DUARTE et al., 2006), its fruits are appreciated by the fauna (PAISE; VIEIRA, 2005), etc. 
Studies on the development of provision of natural goods can contribute to the maintenance of the mixed ombrophilous forest in the landscape. Furthermore, the valuation of such services can improve the perspective of management gains in such a way that the manager receives financial returns from both seed production and ecosystem services.

This work highlights the need for further studies to attempt to replicate this type of information in order to create proper management plans for native resources. Valente et al. (2010) discusses the need for future studies on the species ecology and cone production to obtain viable alternatives for the conservation of this key species. Figueiredo-Filho et al. (2011) mentioned that studies regarding cone production can contribute to the implementation of public laws, aiming to provide economic alternatives for small rural producers. Furthermore, this information could contribute to conservation studies, for example, by projecting population growth using matrices. For example, the work of Davelos and Jarosz (2004), who created transition matrices using just height and d.b.h. size classes. Instead of the reproductive phase of the individuals, the authors used classes considered as "potential reproducers". Therefore, the present study provides classes of potentially reproductive individuals or potential seed producers and, finally, an equation to estimate the probability of encountering an individual in its reproductive phase.

\section{CONCLUSION}

A strong significant relationship exists between size (d.b.h.) and reproductive phase. At the regional scale, this study suggests that the reproductive phase in Araucaria angustifolia begins at 15 and $20 \mathrm{~cm}$ d.b.h. size class. In order to find a greater number of individuals in reproductive stage, the present work shows that a d.b.h. of $35.2 \mathrm{~cm}$ is the minimum required (on a regional scale). Then, this study indicates that an individual must attain a minimal d.b.h. of $35 \mathrm{~cm}$ before its seeds can be harvested. Furthermore, our work suggests that the classes at which the individuals reach maturity varied at the local scale (at site level). Moreover, the size class (d.b.h.) at which the reproductive phase begins also varied.

\section{ACKNOWLEDGEMENTS}

The authors are thankful to the researchers from NPFT - Núcleo de Pesquisas em Florestas Tropicais da UFSC and the Grupo de Pesquisa Uso e Conservação dos Recursos Florestais UDESC/CAV for their assistance; to PROBIC, CNPq and to CAPES, for the financial support to the authors; to EPAGRI/Caçador-SC, Embrapa Florestas, Floresta Nacional de Três Barras, RPPN - Leão da Montanha and Parque Natural Municipal de Lages for their permission to use their experimental area and lodging; to the reviewers, for the contributions to the manuscript; to Rachel Labbé-Bellas for reviewing the English version of the manuscript; to Pedro Volkmer de Castilho, for his contribution to the realization of this work; and to FAPESC, for the financial support.

\section{REFERENCES}

ANSELMINI, J.I.; ZANETTE, F. Development and growth curve of the pine cones of Araucaria angustifolia (Bert.) O. Ktze, in the Region of Curitiba - PR. Brasilian Archives of Biology and Technology, v.51, n.4, p.665-669, 2008.

BITENCOURT, A.L.V.; KRAUSPENHAR, P.M. Possible prehistoric anthropogenic effect on Araucaria angustifolia (Bert.) O. Kuntze expansion during the Late Holocene. Revista Brasileira de Paleontologia, v.9, n.1, p.109-115, 2006.

CRAWLey, M.J. The R Book. West Sussex: John Wiley \& Sons, 2007.

DAVELOS, A.L.; JAROSZ, A.M. Demography of American chestnut populations: effects of a pathogen and a hyperparasite. Journal of Ecology, v.92, p.675-685, 2004.

DRAKE, F.A.; HERRERA, M.A.; ACUÑA, E.C. Propuesta de manejo sustentable de Araucaria araucana (Mol. C. Koch). Bosque, v.26, p.23-32, 2005.

DUARTE, L.S.; DILLENBURG, L.R.

Ecophysiological responses of Araucaria angustifolia (Araucariaceae) seedlings to different irradiance levels. Australian Journal of Botany, v.48, n.4, p.531-537, 2000.

DUARTE, L. D. S.; DOS-SANTOS, M.M.; HARTZ, S. M.,; PILLAR, V. D. Role of nurse plants in Araucaria Forest expansion over grassland in South Brazil. Austral Ecology, v.31, p.520-528, 2006. 


\section{IUCN 2012. IUCN Red List of}

Threatened Species. Version 2012.2.

Disponível em: www.iucnredlist.org. Downloaded on 08 April 2013.

FIGUEIREDO-FILHO, A.; HUBIE, S. do R.; SCHAAF, L. B.; FIGUEIREDO, D. J. de; SANQUETTA, C. R. Avaliação do incremento em diâmetro com o uso de cintas dendrométricas em algumas espécies de uma Floresta Ombrófila Mista localizada no Sul do Estado do Paraná. Ciências Exatas e Naturais, Guarapuava, v. 5 , n. 1, p. $69-84,2003$.

FIGUEIREDO-FILHO, A.; ORELLANA, E.; NASCIMENTO, F.; DIAS, A. N.; INOUE, M. T.

Produção de sementes de Araucaria angustifolia em plantio e em floresta natural no centro-sul do estado do Paraná. Floresta, v.41, n.1, p.155-162, 2011.

HARPER, J.L. Population biology of plants. London: Academic Press, 1977.

HAWLEY, R.C.; SMITH, D.M. Silvicultura prática. Barcelona: Omega, 1972. 544p.

HOPPE, J.M.; CALDEIRA, M.V.W. Correlações entre o crescimento de Araucaria angustifolia (Bertol.) Kuntze, plantada na Floresta Nacional de Passo Fundo, RS, com as características químicas do solo. Revista Acadêmica: Ciências Agrárias e Ambientais, v.1, n.4, p.33-40, 2003.

IBANEZ, M.R. Analisis de la productividad de semillas de Araucaria araucana (Mol.) C. Koch en el area de Lonquimay. Thesis. Santiago: Universidad de Chile, 1984.

IOB, G.; VIEIRA, E.M. Seed predation of Araucaria angustifolia (Araucariaceae) in the Brazilian araucaria forest: influence of deposition site and comparative role of small and 'large' mamals. Plant Ecology, v. 198, p. 185-196, 2008.

LEGENDRE, P.; LEGENDRE, L. Numerical ecology. 2.ed. Amsterdan: Elsevier, 1998.

MANTOVANI, A. Fenologia reprodutiva e estrutura genética de uma população natural de Araucaria angustifolia (Bert.) O. Kuntze (Araucariaceae). 2003. $106 \mathrm{f}$.
Doutorado em Biologia Vegetal) - Universidade Estadual Paulista, Rio Claro, 2003.

MANTOVANI, A.; MORELLATO, L.P.C.; REIS, M.S. Fenologia reprodutiva e produção de sementes em Araucaria angustifolia (Bert.) O. Ktze. Revista Brasileira de Botânica, v.27, n.4, p.787-796, 2004

MATTOS, P. P.; DOS SANTOS, A. T.; RIVERA, H.; de OLIVEIRA, Y. M. M.; ROSOT, M. A. D.; GARRASTAZU, M. C. Crescimento de Araucaria angustifolia na Reserva Florestal Embrapa Epagri, Caçador, SC. Pesquisa Florestal Brasileira, v.55, p.107-114, 2007.

McPHERSON, G.R.; DeSTEFAnO, S. Applied ecology and natural resource management. Cambridge: Cambridge University Press, 2003.

OLIVEIRA, J. M.; SANTAROSA, E.; PILLAR, V. D.; ROIG, F. A. Seasonal cambium activity in the subtropical rain forest tree Araucaria angustifolia. Trees, v.23, p.107-115, 2009.

PAISE, G.; VIEIRA, E.M. Produção de frutos e distribuição espacial de angiospermas com frutos zoocóricos em uma Floresta Ombrófila Mista no Rio Grande do Sul, Brasil. Revista Brasileira de Botânica, v.28, n.3, p.615-625, 2005.

PALUDO, G.F. Estrutura demográfica e padrão espacial de uma população natural de Araucaria angustifolia (Bertol.) Kuntze (Araucariaceae) em Santa Catarina. Revista Árvore, v.33, n.6, p.1109-1121, 2009.

PIETREK, A.G.; BRANCH, L.C. Native plantations as an important element for biodiversity in vanishing forested landscapes: A study of the near threatened araucaria tit spinetail (Leptasthenura setaria, Furnariidade). Austral Ecology, v.36, n.1, p.109-116, 2011.

PUCHALSKY, A.; MANTOVANI, M.; REIS, M.S. Variação em população naturais de Araucaria angustifolia (Bert.) O. Kuntze associada a condições edafo-climáticas. Scientia Forestalis, v.70, n.70, p.137-148, 2006.

R Development Core Team. R: A Language and Environment for Statistical Computing. Vienna: 2012.

Revista Árvore, Viçosa-MG, v.40, n.4, p.695-705, 2016 
REIS, M.S.; PERONI, N.; MARIOT, A.; STEENBOCK, W.; FILIPPON, S. ; VIEIRA-DASILVA, C.; MANTOVANI, A. Uso sustentável e domesticação de espécies da Floresta Ombrófila Mista. In: MING, L.C.; AMOROZO, M.C.M.; KFFURI, C.W. (Ed). Agrobiodiversidade no Brasil: experiências e caminhos da pesquisa. Recife: NUPPEA, 2010. p.183-214.

REIS, M.S.; LADIO, A. Paisajes con Araucarias en Sudamérica: construcciones culturales precolombinas y del presente para producción de alimento. In: NAVARRO, V.; ESPINOSA, S. Paisajes culturales: memorias de las Jornadas de reflexión acerca de los paisajes culturales de Argentina y Chile, en especial los situados en la región Patagónica. Rio Gallegos: AR. ICOMOS / UNPA/ UMAG, 2012. p.224-244.

REITZ, R.; KLEIN, R.M.; REIS, A. Projeto Madeira de Santa Catarina: levantamento das espécies florestais nativas em Santa Catarina com a possibilidade de incremento e desenvolvimento. Itajaí: Herbário Barbosa Rodrigues, 1978. 320p.

REZENDE, J.L.P.; OLIVEIRA, A.D. Análise econômica de projetos florestais. Brasília: UFV, 2011.

RIBEIRO, M. C.; METZGER, J. P.; MARTENSEN, A. C.; PONZONI, F. J.; HIROTA, M. M. The Brazilian Atlantic Forest: How much is left, and how is the remaining forest distributed? Implications for conservation. Biological Conservation, v.142, p.1141-1153, 2009.

ROSOT, M.A.D. Manejo florestal de uso múltiplo: uma alternativa contra a extinção da Floresta com Araucária? Pesquisa Florestal Brasileira, v.55, p.75-85, 2007.

SANGUINETTI, J.; KITZBERGER, T. Patterns and mechanisms of masting in the large-seeded southern hemisphere conifer Araucaria araucana. Austral Ecology, v.33, p.78-87, 2008.

SIMINSKI, A.; FANTINI, A.C. A Mata Atlântica cede lugar a outros usos da terra em Santa Catarina, Brasil. Biotemas, v.23, n.2, p.51-59, 2010.

Revista Árvore, Viçosa-MG, v.40, n.4, p.695-705, 2016
SOLÓRZANO-FILHO, J.A. Demografia, fenologia e ecologia da dispersão de sementes de Araucaria angustifolia (Bert.) O. Kuntze (Araucariaceae), numa população relictual em Campos do Jordão. Dissertação (Mestrado em Ciências Área de Ecologia) - Universidade de São Paulo, São Paulo, 2001.

SOUZA, A.F. Ecological interpretation of multiple population size structures in trees: The case of Araucaria angustifolia in South America.

Austral Ecology, v.32, n.5, p.524-533, 2007.

SOUZA, A. F.; FORGIARINI, C.; LONGHI, S. J.; BRENA, D. A. Regeneration patterns of a longlived dominant conifer and the effects of logging in southern South America. Acta Oecologica, v.34, p.221-232, 2008.

SOUZA, A. F.; DE MATOS, D. U.; FORGIARINI, C.; MARTINEZ, J. Seed crop size variation in the dominant South American conifer Araucaria angustifolia. Acta Oecologica, v.36, p.126$134,2010$.

VALENTE, T.P.; NEGRELLE, R.R.B.; SANQUETTA, C.R. Regeneração de Araucaria angustifolia em três fitofisionomias de um fragmento de Floresta Ombrófila Mista. Iheringia, v.65, n.1, p.17-24, 2010.

VEBLEN, T.T. Regeneration patterns in Araucaria araucana forests in chile. Journal of Biogeography, v.9, p.11-28, 1982.

VIBRANS, A. C.; SEVEGNANI, L.; UHLMANN, A.; SCHORN, L. A.; SOBRAL, M. G.; de GASPER, A. L.; VERDI, M. Structure of mixed ombrophyllous forests with Araucaria angustifolia (Araucariaceae) under external stress in Southern Brazil. Revista de Biologia Tropical, v.59, p.1371-1387, 2011.

VIEIRA-DA-SILVA, C.; REIS, M.S. Produção de pinhão na região de Caçador, $\mathrm{SC}$ : aspectos da obtenção e sua importância para comunidades locais. Ciência Florestal, v.19, p.363-374, 2009.

VIEIRA-DA-SILVA, C.; MARTINS, G.; STEINER, N.; SANTOS, K.L.; CAMARGO, R.; MANTOVANI, 
A.; CUBO, R.R.; GUERRA, M.P.; REIS, M.S. In: CORADIN, L.; SIMINSKI, A.; REIS, A. (Ed).

Espécies nativas da flora brasileira de valor econômico atual ou potencial: Plantas do futuro - Região Sul. Brasília, D.F.: 2011. p.134-150.

ZANDAVALLI, R.B.; DILLENBURG, L.R.; SOUZA, P.V.D. Growth responses of Araucaria angustifolia (Araucariaceae) to inoculation with the mycorrhizal fungus Glomus clarum.

Applied Soil Ecology, v.25, n.3, p.245-255, 2004.

ZANINI, L.; GANADE, G. Restoration of Araucaria Forest: the role of perches, pioneer vegetation, and soil fertility. Restoration Ecology, v. 13, n.3, p.507-514, 2005. 